\title{
On the Diversification of Running Schools in Higher Vocational Colleges
}

\author{
Chao Liu* \\ Department of Computer, Wuhan polytechnic, Wuhan 430074, China \\ *Corresponding author. Email: 522152907@qq.com

\begin{abstract}
In order to sustainable development, higher vocational colleges need to use the power of society to realize a multieducational running system. The social forces mainly include: relying on the industry, cooperate with enterprises, Chinese-foreign cooperatively-run schools, and other forms.
\end{abstract}

Keywords: Relying on industry, Cooperate with enterprises, Chinese-foreign cooperatively-run school.

\section{HIGHER VOCATIONAL COLLEGE EDUCATION SUSTAINABLE DEVELOPMENT}

Higher education sustainable development refers to the development of sustainable intellectual support and talent support for economic and social development. At the same time, the development of society promotes the sustainable development of education.

As a type of higher education, higher vocational education is not only an important force to promote the sustainable development of economy and society, but also a need for the sustainable development of society and higher vocational education itself. On the one hand, the sustainable development of higher vocational education itself is an important part of the sustainable development of economy and society, which provides an important educational guarantee for the sustainable development of economy and society. On the other hand, the sustainable development of education is also the basic requirement of educational development.

\section{HOW TO CONSTRUCT THE MULTI- SUBJECT RUNNING SYSTEM OF HIGHER VOCATIONAL COLLEGES}

It is necessary to construct a multi-subject running system of higher vocational colleges in the absence of special developed economy and limited social resources. Mainly include: relying on industry running schools, cooperating with enterprises, Chinese-foreign cooperatively-run schools, state-owned privately run schools.

\subsection{Relying on Industry}

The connotation of higher vocational education by "higher education" and "professional education" dual concept, which decides the higher vocational education and general education is one of the important differences between the professional, is the industry. The higher professional education has an inherent and necessary link between the industry and the enterprise, which shows the dependence and relevance of education to the industry and enterprise resources. Industry resources refer to the industry competent government and industry service organizations (industry associations or chamber of commerce). Industry resources refer to the industry competent government and industry service organizations (industry associations or chamber of commerce), various kinds of material resources and human resources possessed by various social organizations at the core of industry enterprises. Therefore, one of the effective ways of marketization strategy of higher vocational colleges is to rely on industry to run schools.

Colleges and universities should rely on the industry to run schools, mainly because the industry resources and industry information can complement and support the education of higher vocational colleges. If relying on industry cooperation, vocational colleges can hire professional staff to teach and guide the training. The machine equipment and material means of the industry department can become the resources for the internship and training of higher vocational students. The resource sharing is to enable students to contact the actual equipment in the industry and understand the related 
background, dynamic and development prospect of the industry.

Relying on the core of the industry, it is oriented towards the market, developing the way of development and outward orientation, and taking resources to the industry to serve the industry.

(1) The communication between higher vocational colleges and industries, enterprises and government departments

Higher vocational colleges establish close contact with government departments related industry, promote the mutual understanding, through the friendly communication, setting up the social image of the school and the professional, to win the trust of industry, government departments, ensure industry policy support from government agencies. From the perspective of government management, new problems and new requirements can be learned in time. From the perspective of government behavior, we can organize the project development projects with market potential and promotion activities.

(2) Communication between teachers and the market

The teaching of higher vocational colleges should combine theoretical teaching with practice teaching, and professional teaching and vocational skills should be closely combined, which must be realized through teachers in higher vocational colleges. So professional teachers in higher vocational colleges must be familiar with related industry, understand the market, timely grasp the practical problems in the development of industry and the theory of the new hot spot, make the classroom teaching is not only a theoretical, more practical, practicality, it is very important in higher vocational teaching. Only by relying on the industry, have the opportunity to contact the industry, can deep in the industry position, make the teacher in the higher vocational colleges have the destination in the industry post long - term practice.

\subsection{Cooperate with Enterprises in Running Schools}

Now, higher vocational colleges in the schoolrunning practice is generally know to contact the enterprise to strengthen the personnel training mode reform is an effective way of some higher vocational colleges has been underway for the attempt.

(1) Relying on the advantages of the enterprise, it provides teachers and venues for the practice teaching of education. Companies advanced technology and equipment and rich practical experience of technical staff technical application ability training for students to create the good conditions, university-enterprise cooperation, complementary advantages, fully ensure the implementation of the talents training goal of higher vocational education. Such as the higher vocational college of Tongji University and Shanghai diesel engine co., LTD., adopt the training mode of " $2+1$ ", the first two years in college to carry on the theoretical study, a year after post practice in Shanghai diesel engine co., LTD., can develop together in the first line for CNC airport operation, commissioning, programming, and mechanical and electrical integration of the personnel management.

(2) Cooperate with enterprises to carry out "ordering" personnel training

The main feature of this model is that higher vocational colleges should target students according to the "orders" of enterprises, orientation training, or enterprise employees to higher vocational colleges to receive training. The teaching plan of this kind of model generally has the school enterprise both sides to develop jointly. Colleges accept orders from businesses. According to the specific requirements of enterprises, design knowledge structure, capability structure, determine training plan, and construct the teaching system of theory and practice. In the teaching organization, the "sandwich" teaching is implemented, the management of the management adopts the post management, and the students enter the enterprise directly after graduation. This ordering education training mode, did it personnel training in the work "- the cultivating process - export" organic unity, greatly reducing the students qualified for jobs they persevered, realize win-win situation college and enterprise.

The above two modes are the most common pattern adopted by colleges and universities. These two modes play a positive role in enhancing the education vitality of higher vocational colleges. With the deepening of enterprise reform and relevant national policies to further improve, higher vocational colleges should seize the current opportunity, increase the intensity of innovation, exploring university-enterprise cooperation all-round multi-level joint ventures.

\subsection{Chinese-foreign Cooperatively-run School}

1. Government management, guidance and policy support are the important guarantee for the stable development of Sino-foreign cooperation in higher vocational colleges. First, give play to the role of government oversight and regulation. The quality of Chinese-foreign cooperation in running schools is closely related to the government's supervision of Chineseforeign cooperation in running schools. At present, the examination and approval of the Ministry of Education has been reviewed and evaluated, completed the supervision of the process of the existing Chinese-foreign cooperation in running schools, and ensured the quality of Chinese-foreign cooperation in running schools. Therefore, it is necessary for provinces, autonomous 
regions and municipalities to establish corresponding evaluation, evaluation standards, supervision and evaluation mechanism for the level of Chinese-foreign cooperation in higher vocational schools. The existing higher vocational Chinese-foreign cooperation in running schools regularly system evaluation, timely expose existing professional, certificate, cooperation, progress and running effect, etc., avoid duplication of set, low professional level, to provide foreign students without substantial cooperation and other issues, grasp the Chinese-foreign cooperation in running schools in the public welfare principle, ensure the quality of Chineseforeign cooperation in running schools of education.

Secondly, strengthen the management and guidance of Sino-foreign cooperation in running schools. Due to the profit-making characteristics of some foreign colleges and universities, it is necessary for the government to implement effective supervision over Chinese-foreign cooperation in running schools. However, the contradiction between policy supervision and the profit-making nature of cooperative colleges and universities will often lead to the phenomenon of "death or chaos as soon as we catch or let go", which will affect the development of Chinese-foreign cooperation in running schools. Therefore, while improving the policy content and implementing effective supervision, the government should actively provide more high-quality education resources for higher vocational colleges by organizing international cooperation platforms and information exchange mechanisms such as education exposition and international alliance of higher vocational education, so as to guarantee the public interest nature of running schools and promote the healthy development of Sino-foreign cooperation in running schools in higher vocational colleges.

Finally, provide policy support. Policy support is very important for the development of Sino-foreign cooperation in running schools. The government can provide support for higher vocational colleges through financial support, information sharing, infrastructure construction and other ways. At the same time, we should strengthen the propaganda and interpretation of the policy of Chinese-foreign cooperation in running schools, create a positive and good policy atmosphere, improve the public's recognition of Chinese-foreign cooperation in running schools, and form a virtuous circle of enrollment, teaching, employment and other links of Chinese-foreign cooperation in running schools. In addition, the cooperation between different government departments should be strengthened to provide more convenience for the establishment and implementation of Sino-foreign cooperation in running schools, so as to improve the enthusiasm of higher vocational colleges in carrying out Sino-foreign cooperation in running schools.

2. The school strengthens the awareness, improves the level, and improves the mechanism to enhance the level and quality of Sino-foreign cooperation in higher vocational education. First of all, strengthen the sense of internationalization. Higher vocational colleges should realize the implementation of the internationalization of Chinese-foreign cooperation in running schools this particular form, is the inevitable trend in the new stage of higher vocational education development, the internal demand of the construction of the "combination", higher vocational colleges, especially the "twin" colleges and universities should be Chinese-foreign cooperation in running schools into the school development plan with internationalization, enhance internationalization consciousness, build internationalized atmosphere actively, needs and goals of school development and major construction, analysis the function and significance of the Chinese-foreign cooperation in running schools, active exploration in higher vocational colleges to carry out the feasibility and the advantages and disadvantages of the Chinese-foreign cooperation in running schools, actively carry out the Chinese-foreign cooperation in running schools. Second, step up highlevel cooperation. Current higher vocational level and quality of Chinese-foreign cooperation in running schools in general is not high, related to higher vocational colleges and universities own development level and ability, thus improving the quality of Chinese-foreign cooperation in running schools in higher vocational colleges should first strengthen the high level of cooperation, higher vocational colleges should take the initiative to assessment of qualifications, level of foreign cooperation and influence in the industry, actively seek high levels of colleges and universities with foreign cooperation, the introduction of high-quality educational philosophy, curriculum and professional standards, a high level of teaching staff and the appraisal mechanism; Through consultation and negotiation, we strive for the maximization of resource acquisition in the process of cooperation, so as to continuously improve the quality of talent training and the level of cooperation in running schools.

3. Finally, an internal quality assurance system should be established.Higher vocational colleges and universities to promote the development of sino-foreign cooperation in running schools, you must first identify Chinese-foreign cooperation in running schools in resources introduction, professional construction, faculty development, talent training, the important role of quality improvement, etc, the Chinese-foreign cooperation in running schools to develop organic integrated into the development process of higher vocational colleges, from requirements analysis, set up conditions, operation mechanism, implementing process, evaluation feedback, the system guarantee, form organic circulation, stimulate endogenous dynamic of sino-foreign cooperation in running schools, establish Chinese-foreign cooperation in running schools guarantee and supervision system, explore the Chinese-foreign cooperation in running 
schools train of thought and pattern innovation, so as to give full play to the functions of Chinese-foreign cooperation in running schools, Achieve the coordinated development of Sino-foreign cooperation in running schools and higher vocational colleges. Higher vocational colleges should seize the historical opportunity of the construction of the "combination", the development of sino-foreign cooperation in running schools and to build a "twin", highlight the characteristics of colleges and universities and professional construction, establish Chinese-foreign cooperation in running schools and coordinated operation and guarantee mechanism of the development of specialty construction, from the management structure, department coordination, policy support and other aspects to obtain, effective play to the role of Chinese-foreign cooperation in running schools in specialty construction, formed with specialty as the core of new path, the new model of cooperation in running schools.

\section{CONCLUSION}

In order to continue to develop, higher vocational colleges must use social forces to carry out reform on the main body of the school and realize the diversified running body. Only in this way can the sustainable development of higher vocational colleges spring.

\section{REFERENCES}

[1] Yi XIAO: Various model schools, vigorously develop professional education. Chinese Vocational and Technical Education. 2001(5).

[2] Zheng NIU. Professional education main body diversity study. Educational Research. 2001(8),5862.

[3] Australian Qualification Framework. Implmentation Handbook, Second Edition,1998.

[4] Mike Flude, Sandt Sieminski. Education, Training and the Future of Work II: Developments in Vocational Education and Training. Paris:OECD,1999.

[5] Jin-xiang FENG. Chinese and foreign higher professional education comparison. Beijing: Higher education press,2002.

[6] De-guang YANG. Advanced education monograph. Shanghai: Shanghai education press,1998. 